http://dx.doi.org/10.18778/1643-0700.17.06

\author{
Elżbieta JARCZAK*, Agnieszka LITWA**
}

\title{
WYPOSAŻENIE KOŚCIOŁA ŚW. WAWRZYŃCA W ROSSOSZYCY ${ }^{1}$
}

Streszczenie. Kościół św. Wawrzyńca w Rossoszycy (gmina Warta) to jedna z ciekawszych budowli sakralnych XVIII w. znajdująca się w diecezji włocławskiej. Piękny, modrzewiowy kościół przechodzi obecnie gruntowny remont. Wyposażenie kościoła pochodzące w głównej mierze z XVIII w. to trzy ołtarze z wyjątkowymi rzeźbami, prawdopodobnie dłuta zakładu snycerskiego Franza Eytnera, artysty pochodzącego z Kalisza, słynącego z ekspresyjności rzeźb. Na uwagę zasługuje również XIX wieczna, drewniana ambona jak i prospekt organowy.

Słowa kluczowe: kościół pw. św. Wawrzyńca w Rossoszycy, wyposażenie kościoła św. Wawrzyńca w Rossoszycy.

Pochodzący z drugiej połowy XVIII w. modrzewiowy kościół pw. św. Wawrzyńca w Rossoszycy (woj. łódzkie) jest już trzecią z kolei świątynią wybudowaną w tym miejscu. O wyposażeniu wnętrz wcześniejszych obiektów niewiele wiadomo. Zachował się krótki opis wyposażenia pierwszej świątyni w dokumentach z wizytacji przeprowadzonej w 1683 r. ${ }^{2}$ Kościół posiadał wówczas trzy pozłacane ołtarze z drewna: ołtarz główny z wizerunkiem Koronacji Najświętszej Maryi Panny oraz ołtarze boczne - św. Antoniego i Najświętszej Maryi Panny. Powyższy spis wymienia także drewnianą chrzcielnicę ustawioną w rogu kościoła.

Drugi kościół, wzniesiony w latach 1770-1773, zgodnie z zapisami z wizytacji dekanalnej przeprowadzonej w 1779 r. posiadał trzy ołtarze: pierwszy wielki -św. Wawrzyńca, pod którego tytułem jest kościót, drugi po prawej stronie NMP

* Elżbieta Jarczak, dyrektor Miejskiej i Gminnej Biblioteki Publicznej w Szadku, ul. Prusinowska 4, 98-240 Szadek, e-mail: elajarczak@o2.pl.

** Agnieszka Litwa, mgr historii sztuki, Katedra Historii Sztuki Uniwersytetu Łódzkiego, ul. Jana Lechonia 4/27, 95-100 Zgierz, e-mail: agn.mad_hatter@wp.pl.

1 Artykuł powstał na podstawie pracy licencjackiej Agnieszki Litwy, Kościót św. Wawrzyńca $w$ Rossoszycy. Monografia, Uniwersytet Łódzki, Wydział Filozoficzno-Historyczny, Łódź 2014 (za zgodą autorki).

2 Archiwum Diecezjalne we Włocławku (dalej: ADW), sygn. Archiwum Arcybiskupów Gnieźnieńskich (dalej: AAG). Wiz. 8, Acta visitationis Archidiaconatus Vnieioviensis [...] in anno Dni 1683-tio felicitier expeditae, s. 56. 
Częstochowskiej, trzeci po lewej stronie św. Antoniego, wszystkie stare bo ze starego kościoła ${ }^{3}$.

Dzisiejsze wyposażenie kościoła pw. św. Wawrzyńca w Rossoszycy stanowi ołtarz główny (z końca XVIII w.) ulokowany w zamknięciu prezbiterium, dwa ołtarze boczne (XVIII w.) umieszczone w kaplicach przy ścianach wschodnich, ambona z XIX w., zawieszona na ścianie północnej prezbiterium oraz prospekt organowy z XIX w. umieszczony na ścianie zachodniej, na chórze muzycznym.

\section{OŁTARZ GŁÓWNY}

Ołtarz główny, wykonany z drewna, jest najstarszym elementem wyposażenia kościoła ${ }^{4}$, datowanym na czwartą część XVIII w., w całości bogato zdobiony dekoracją snycerską $w$ postaci ornamentu rocaillowego ${ }^{5}$. Ołtarz jest jednokondygnacyjny, jednoosiowy z bramkami po bokach. Składa się z podstawy z wyodrębnioną mensą, kolumnowego retabulum ${ }^{6}$ oraz zwieńczenia na osi. Mensa ołtarzowa ma kształt sarkofagu zwężającego się u podstawy. Kompozycję retabulum tworzą pełnoplastyczne kolumny, po dwie z każdej strony. Dźwigają one gierowane ${ }^{7}$ belkowanie, na którym spoczywa przerwany naczółek i zwieńczenie. Kolumny o gładkich trzonach i kompozytowych kapitelach ustawione są uskokowo na wysokich cokołach. W prześwitach między kolumnami usytuowana jest para pilastró $\mathrm{w}^{8} \mathrm{~W}$ analogicznym porządku. Za wysuniętymi kolumnami strukturę ołtarza tworzą płaszczyzny zdobne w ciągły motyw liści akantu, umieszczony na wysokości kapiteli kolumn i pilastrów. Pomiędzy kolumnami, na niskich cokołach o rzucie czworobocznym, ustawione są drewniane rzeźby pełnoplastyczne, przedstawiające św. Mikołaja po lewej i św. Walentego po prawej stronie.

3 ADW, sygn. AAG. Wiz. 73, Wizyta generalna do Decanatów Radomskiego, Brzeźnickiego i Lutomierskiego [w Archidiakonacie Uniejowskim] delegowanego wizytatora roku Pańskiego 1779 odprawiona, s. 405.

${ }^{4}$ Katalog zabytków sztuki w Polsce, t. II: Województwo łódzkie, red. J. Łoziński, z. 10, Warszawa 1953, s. 17.

5 Rocaille - motyw dekoracyjny stosowany od ok. 1730 r., naśladujący muszle, małżowiny uszne, fale morskie, koguci grzebień. Zob. W. Szolginia, Architektura, Sigma NOT, Warszawa 1992, s. 136.

6 Retabulum - nastawa ołtarza jedno- lub wielokondygnacyjna spoczywająca na mensie lub rozbudowana $\mathrm{w}$ formie dekoracyjnej ściany parawanowej za ołtarzem, zdobiona rzeźbami i malowidłami. Zob. Wielka Encyklopedia Powszechna, t. 9, PWN, Warszawa 1967, s. 802.

7 Gierowanie - krępowanie gzymsu, zob. K. Krajewski, Mała encyklopedia architektury i wnętrz, Zakład Narodowy Ossolińskich, Wrocław 1974, s. 243. Gierowanie - wyłamanie części belkowania znajdującej się nad kolumną lub pilastrem. Zob. Sztuka świata, t. 17: Stownik terminów A-K, Arkady, Warszawa 2013, s. 221.

8 Pilastry - filary ustawione tuż przy ścianie, pełniące rolę dekoracyjną, ale często podtrzymujące także budowlę. Zob. Stownik terminologiczny sztuk pięknych, red. S. Kozakiewicz, Warszawa 1969. 

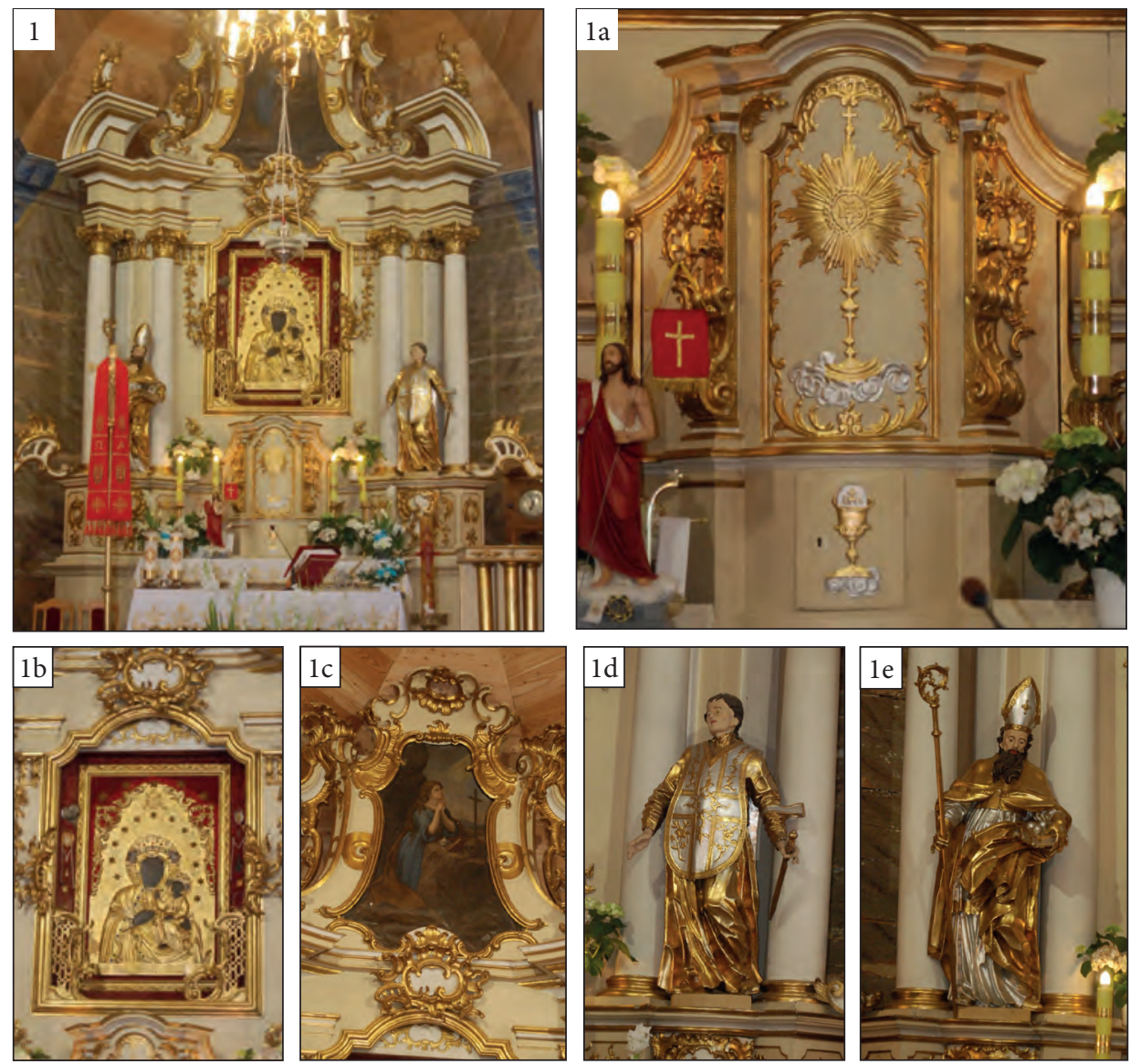

Fot. 1. Ołtarz główny kościoła św. Wawrzyńca w Rossoszycy

1a - tabernakulum, 1b - obraz Matki Bożej z Dzieciątkiem Jezus,

1c - obraz św. Marii Magdaleny, 1d - rzeźba św. Walentego, 1e - rzeźba św. Mikołaja Źródło: zdjęcia J. Pośpieszyński [12.05.2017]

Rzeźba św. Mikołaja to postać z rękoma ugiętymi w łokciach, trzymająca atrybuty w dłoniach. W prawej ręce święty trzyma pastorał, natomiast lewa dłoń podtrzymuje oparta o biodro dużą księgę, na której umieszczone są trzy kule. Twarz świętego jest owalna. Wyraz nadają jej podniesione łuki brwiowe, głęboko osadzone oczy, wydatny nos, ostre, wystające kości policzkowe i wąskie rozchylone usta ${ }^{9}$. Twarz, zwróconą w lewą stronę, okala długa, falująca broda,

9 Zauważalne są pewne związki formalne rzeźb ołtarzowych $\mathrm{z}$ warsztatem snycerskim Franza Eytnera, artysty pochodzącego z Kalisza. Zob. P. Migasiewicz, Dzieła rzeźbiarza Franza Eytnera na terenie dawnych ziem tęczyckiej i sieradzkiej, [w:] Sztuka Polski Środkowej. Studia V, red. P. Gryglewski, E. Kubiak, K. Stefański, Łódź 2011, s. 65-87. W artykule zamieszczona jest ogólna charakterystyka rzeźb artysty, która mocno przypomina postacie rzeźb z ołtarza. Może to wskazywać, że niektóre z nich zostały wykonane przez rzemieślników z warsztatu Eytnera. 
a spod mitry widać spływające na kark miękkie włosy. Postać jest ubrana w strój biskupi. Długa alba, sięgająca do stóp, jest przepasana pasem biskupim. Na ramiona świętego zarzucony jest płaszcz z lamówką, spięty dekoracyjnie pod szyją. Fałdy szat układają się miękko, a wgniecenia i marszczenia lewej poły płaszcza dają ciekawe efekty fakturalne.

Postać św. Walentego ${ }^{10}$ ciężar ciała przenosi na prawą, wysuniętą do przodu nogę. Święty ma ręce lekko ugięte, oddalone od tułowia $i$ wyciągnięte do przodu. W lewej dłoni trzyma długi nóż. Z odchyloną do tyłu głową, kieruje wzrok ku prawemu ramieniu. Włosy lekko opadają mu na kark. Twarz postaci jest pociągła, z prostym nosem i wydatnymi ustami. Ubiór świętego to długa alba przewiązana w pasie, na którą zarzucony jest ornat $\mathrm{z}$ bogatymi aplikacjami. Draperia szaty wyrzeźbiona jest niezwykle ekspresyjnie, co sprawia, że postać wydaje się lekka i zwiewna.

W zwieńczeniu ołtarza głównego, w ramie o wykroju kartuszowym ${ }^{11}$, obwiedzionej ornamentem rocaillowym, umieszczony jest obraz św. Marii Magdaleny $^{12}$. Jest to obraz olejny na płótnie, przycięty i przymocowany do deski. Prawdopodobnie namalowany w czasie budowy ołtarza głównego, czyli ok. 1783-1786 r. Kompozycja obrazu jest statyczna, dwuplanowa. Maria Magdalena klęczy z dłońmi złożonymi do modlitwy przy skale tworzącej stół, na którym znajduje się krzyż, czaszka, puszka z wonnościami i otwarta księga. Postać ubrana jest $\mathrm{w}$ długą suknię przewiązaną $\mathrm{w}$ pasie oraz narzucony na ramiona płaszcz. Długie falujące włosy opadają jej na ramiona i plecy. Z tyłu, za świętą, widać urwisko skalne oraz fragmenty uproszczonego krajobrazu. Kolorystyka obrazu mieści się w szarości, zieleni i błękicie.

W centralnej części retabulum, w profilowanej ramie o wykroju prostokąta zakończonego od góry łukiem wklęsło-wypukłym uskokowym, umieszczony jest obraz z przedstawieniem Matki Boskiej Częstochowskiej ${ }^{13}$. Jest to główny obraz ołtarza. Ukazuje on najstarszy i najbardziej rozpowszechniony typ ikonograficzny przedstawień Matki Bożej z Dzieciątkiem Jezus - Hodegetria ${ }^{14}$. Matka $\mathrm{z}$ Dzieciątkiem na lewym ramieniu, w geście przedstawienia ludowi Syna Bożego, z nieznacznie skierowaną ku Dzieciątku głową, wskazuje je prawą dłonią.

10 Figurę świętego błędnie identyfikowano ze św. Wawrzyńcem w: Katalog zabytków sztuki w Polsce, t. II, z. 4, s. 17. Błąd powielono również w dokumentacji konserwatorskiej oraz „Rocznikach Diecezji Włocławskiej” z lat 1991 i 2011. Jednak już w wizytacji parafii z 1786 r. rzeźba identyfikowana jest z postacią św. Walentego, który w ikonografii przedstawiany jest w stroju kapłana z mieczem i kielichem.

11 Kartusz - ozdobne obramowanie herbu, napisu, malowidła. Zob. przyp. 7.

12 Katalog zabytków sztuki w Polsce, t. II, z. 4, s. 17.

13 Brak informacji o obrazie w Katalogu zabytków sztuki w Polsce i dokumentacji konserwatorskiej, wobec czego trudno określić czas pojawienia się obrazu w ołtarzu głównym oraz jego wartość artystyczną.

14 Hodegetria - „Wskazująca drogę”, najstarszy i najbardziej rozpowszechniony typ ikonograficzny przedstawienia Matki Bożej z Dzieciątkiem Jezus na ręku. Zob. W. Łosski, Hodegeria-Putiwoditielnica, „Przegląd Prawosławny” 2002, nr 8 (206), http://www.przegladprawoslawny.pl/articles.php?id_n=169\&id=8 [dostęp 7.05.2017]. 
Chrystus z głową lekko obróconą, w lewej dłoni trzyma księgę, prawą zaś unosi w geście błogosławieństwa. Głowy postaci ozdobione są otwartymi koronami. Twarze i dłonie malowane bardzo ciemno, techniką olejną. Złote szaty Maryi i Chrystusa pokryte są aplikacjami imitującymi kamienie szlachetne. Całość umieszczona jest na czerwonej tkaninie, na której rozwieszone są wota. Obraz ten 10 sierpnia, w dzień odpustu parafialnego, jest zasłaniany zasuwą z wizerunkiem św. Wawrzyńca, patrona kościoła.

Postać św. Wawrzyńca to obraz olejny na płótnie z poł. XIX w. ${ }^{15}$ Kompozycja statyczna, dwuplanowa. W centralnej części obrazu ukazana jest en face stojąca postać świętego z palmą męczeństwa w prawej dłoni. Ubiór świętego to alba sięgająca do stóp oraz założony na nią ornat. Święty stoi obok wielkiego rusztu, narzędzia swojego męczeństwa. Wokół głowy świętego unoszą się uskrzydlone główki putt ${ }^{16}$ otoczone chmurkami.

Poniżej obrazu, na mensie, ustawione jest tabernakulum o złożonym wielobocznym kształcie. Front tabernakulum zawiera dekoracyjną płycinę, w której mieści się płaskorzeźbiona monstrancja unosząca się na chmurach.

Bramki ołtarza tworzone są przez słupki ustawione przy ścianach prezbiterium, połączone rocaillową formą z cokołem retabulum. Na słupkach bramek ustawione są wazy zdobione ornamentem rocaillowym.

Forma ołtarza odznacza się wysokim poziomem wykonania. Szczególnie widać to w wykonaniu draperii szat świętych oraz drobnych dekoracji snycerskich w postaci rocailli. Kolorystyka ołtarza utrzymuje się w odcieniach bieli, beżu i złota.

\section{OŁTARZE BOCZNE}

W kaplicach północnej i południowej znajdują się dwa ołtarze boczne wykonane pod koniec XVIII w., jednoosiowe, zdobione dekoracją snycerską. Mensa ołtarzowa zachowana $\mathrm{w}$ formie sarkofagowej, zdobiona jest centralnie ornamentem rocaillowym i wydłużonymi liśćmi okalającymi jej naroża. W ołtarzach umieszczone są po dwa obrazy i dwie rzeźby. Obraz główny, umieszczony w centrum nastawy, ujęty jest dwiema kolumnami o gładkich trzonach i kompozytowych kapitelach. Na skrajach ołtarzy, pomiędzy dwoma pilastrami, na niskich, czworobocznych cokołach ustawione są rzeźby z XVIII w. Na głowicach kolumn i pilastrów spoczywa wydatne belkowanie, wieńczone puttami i wazami płomienistymi. Zwieńczenie, ukształtowane $\mathrm{w}$ formie glorii, umieszczone jest w owalu wśród chmurek i główek putt. Na mensie ołtarza w kaplicy południowej, w centralnym, ozdobnym rocaillowym kartuszu widnieje data: A:D: 1798.

W ołtarzu bocznym kaplicy północnej znajdują się dwie rzeźby - św. Anny i św. Rocha oraz obraz Trójcy Świętej/Świętej Rodziny i Serca Jezusa.

15 Katalog zabytków sztuki w Polsce, t. II, z. 4, s. 17.

16 Putto - motyw dekoracyjny przedstawiający małego nagiego chłopca. W okresie baroku określenie stosowane do postaci aniołków, dekoracji kościelnych. Zob. Słownik terminologiczny sztuk pięknych, Wyd. Naukowe PWN, Warszawa 2007, s. 339. 

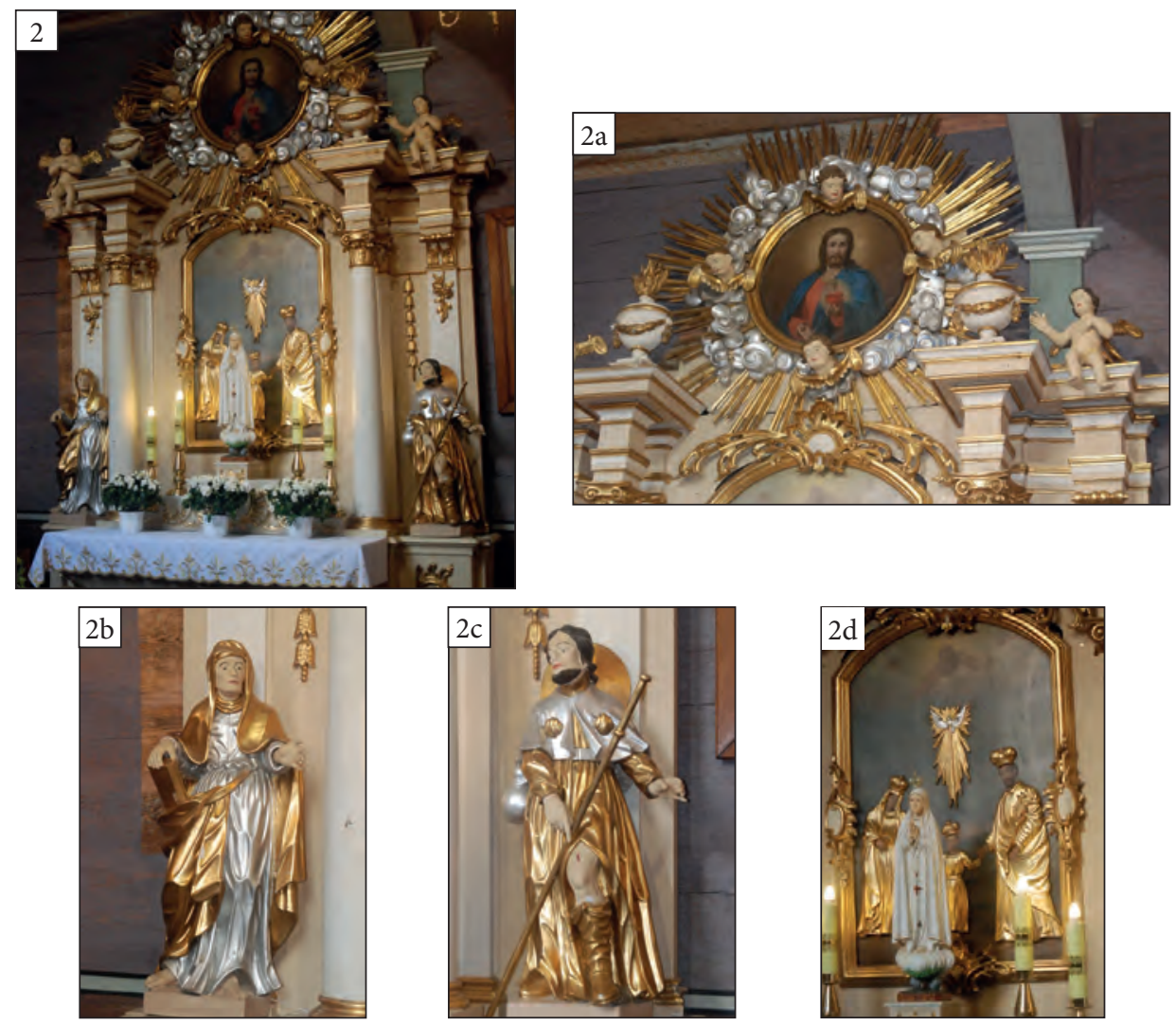

Fot. 2. Ołtarz kaplicy północnej w kościele św. Wawrzyńca w Rossoszycy $2 \mathrm{a}$ - obraz Serce Jezusa, 2b - rzeźba św. Anny, 2c - rzeźba św. Rocha, 2d - obraz Świętej Rodziny Źródło: zdjęcia J. Pośpieszyński [12.05.2017]

Św. Anna, matka Maryi, ukazana jest w silnym kontrapoście ${ }^{17}$. Ręce ma unie sione, ugięte w łokciach. Prawa dłoń podtrzymuje wspartą na biodrze księgę, lewa dłoń pozostaje rozwarta. Głowa świętej okryta jest chustą i uniesiona lekko ku górze. Twarz kobiety jest pociągła, z głęboko osadzonymi oczami, z wydatnymnosem i pełnymi ustami. Postać ubrana jest w długą, sięgającą bosych stóp suknię, przewiązaną w pasie. Na ramionach ma płaszcz, podwiązany na wysokości bioder, lekko zebrany z prawej strony. Kanon proporcji figury jest przysadzisty, dłonie i stopy wykonane są bardzo realistycznie, sprawiają wrażenie zbyt dużych w stosunku do całej postaci. Widoczna jest pewna deformacja proporcji rzeźby, wynikająca z przeznaczenia jej do oglądania w skrócie perspektywicznym.

17 Kontrapost - zasada kompozycji w rzeźbie, polegająca na ustawieniu postaci ludzkiej tak, aby ciężar ciała spoczywał na jednej nodze. Dla zrównoważenia postawy tułów i ramiona są odchylone w stronę przeciwną, co sprawia wrażenie, że postać stoi naturalnie, swobodnie. Zob. M. Porębski, Dzieje sztuki w zarysie. Od paleolitu po wieki średnie, t. 1, Arkady, Warszawa 1976. 
Św. Roch to postać ukazana w kontrapoście, z głową lekko odchyloną do tyłu, skierowaną w prawą stronę. Twarz świętego okolona jest zarostem i falującymi włosami sięgającymi karku. Święty ubrany jest w długą szatę sięgającą do stóp. Spod szaty odsłania się lewa noga obuta w wysoki but. Na nodze widoczna jest rana. Prawą ręką, opuszczoną wzdłuż ciała, postać wskazuje na ranę, lewą ręką, lekko oddaloną od tułowia, trzyma długi kij. Na ramionach postaci zarzucona jest krótka peleryna spięta pod szyją i duży kapelusz opuszczony na plecy. Obraz Trójcy Świętej, główny obraz retabulum północnego ołtarza bocznego, to olej na płótnie z ok. poł. XIX w. Jest to kopia obrazu z kolegiaty kaliskiej malowana przez warsztat lokalny ${ }^{18}$. Kompozycja obrazu jest statyczna, dwuplanowa. Postacie przedstawione są en face, umieszczone w dwóch osiach - pionowej i poziomej. Na postacie Trójcy Świętej założone są drewniane, złocone sukienki oraz zamknięte korony. W centralnej części obrazu widzimy postać młodego Jezusa w długiej sukience. Nad nim, w promienistej glorii, widnieje gołębica, a powyżej w chmurach Bóg Ojciec i główki aniołków. Po prawej stronie Jezusa stoi Maria, ubrana w suknię sięgającą do stóp, z książką w dłoni. Natomiast po lewej stronie stoi św. Józef, w długiej szacie, z płaszczem przerzuconym przez ramię, trzymając lilię w lewej dłoni. Scena umieszczona jest w tle uproszczonego $\mathrm{w}$ formie krajobrazu, utrzymanego w jasnej tonacji. Serce Jezusa jest to obrazem współczesnym, zamieszczonym w okrągłej ramie zwieńczenia ołtarza.

W ołtarzu bocznym kaplicy południowej znajdują się rzeźby św. Apolonii i św. Wojciecha, jak również obrazy św. Antoniego i Serca Maryi.

Św. Apolonia to postać ukazana w kontrapoście. Jej głowa okolona jest długimi włosami, w luźnych puklach spadających na ramiona. Twarz świętej jest owalna. Postać ma prosty nos i wydatne usta. Ręce są ugięte w łokciach, odchylone od ciała. Na dłoniach zawieszony jest sznur pereł. Św. Apolonia ubrana jest w suknię przewiązaną pasem, sięgającą do bosych stóp oraz płaszcz przerzucony przez lewe ramię, obficie drapowany, opadający ku lewej stopie.

Św. Wojciech to rzeźba ukazana w lekkim kontrapoście, z prawą ręką uniesioną ku górze $\mathrm{w}$ geście błogosławiącym. Lewa ręka postaci jest opuszczona, lekko odchylona od ciała, trzyma atrybut w postaci pastorału. Święty Wojciech ma głowę pochyloną do przodu. Jego twarz, okoloną zarostem i falującymi włosami opadającymi na kark, cechuje prosty, wydatny nos i pełne usta. Ubiór świętego to długa alba, na którą nałożona jest krótka, sięgająca do kolan rokieta, obszyta od dołu szeroką koronką. Na ramiona postaci narzucona jest ozdobna kapa, spięta na piersi szeroką zapinką. Ubiór uzupełnia mitra na głowie świętego oraz długie rękawice na dłoniach.

Obraz główny ołtarza bocznego przedstawia św. Antoniego. Jest to obraz współczesny, malowany w technice olejnej na płótnie. Przedstawia on ubranego w habit świętego, klęczącego przed Dzieciątkiem, które stoi na otwartej księdze unoszącej się na chmurce. Twarz świętego, zwrócona ku Dzieciątku, wyraża uwielbienie i zachwyt. Obok kolan klęczącego leży biała lilia.

18 Wojewódzki Konserwator Zabytków, Delegatura w Sieradzu, Karta ewidencyjna zabytku ruchomego, zał. Ewa Kozołup, 1993. 
Serce Maryi, współczesny obraz umieszczony w okrągłej ramie zwieńczenia ołtarza - olejny malowany na płótnie.
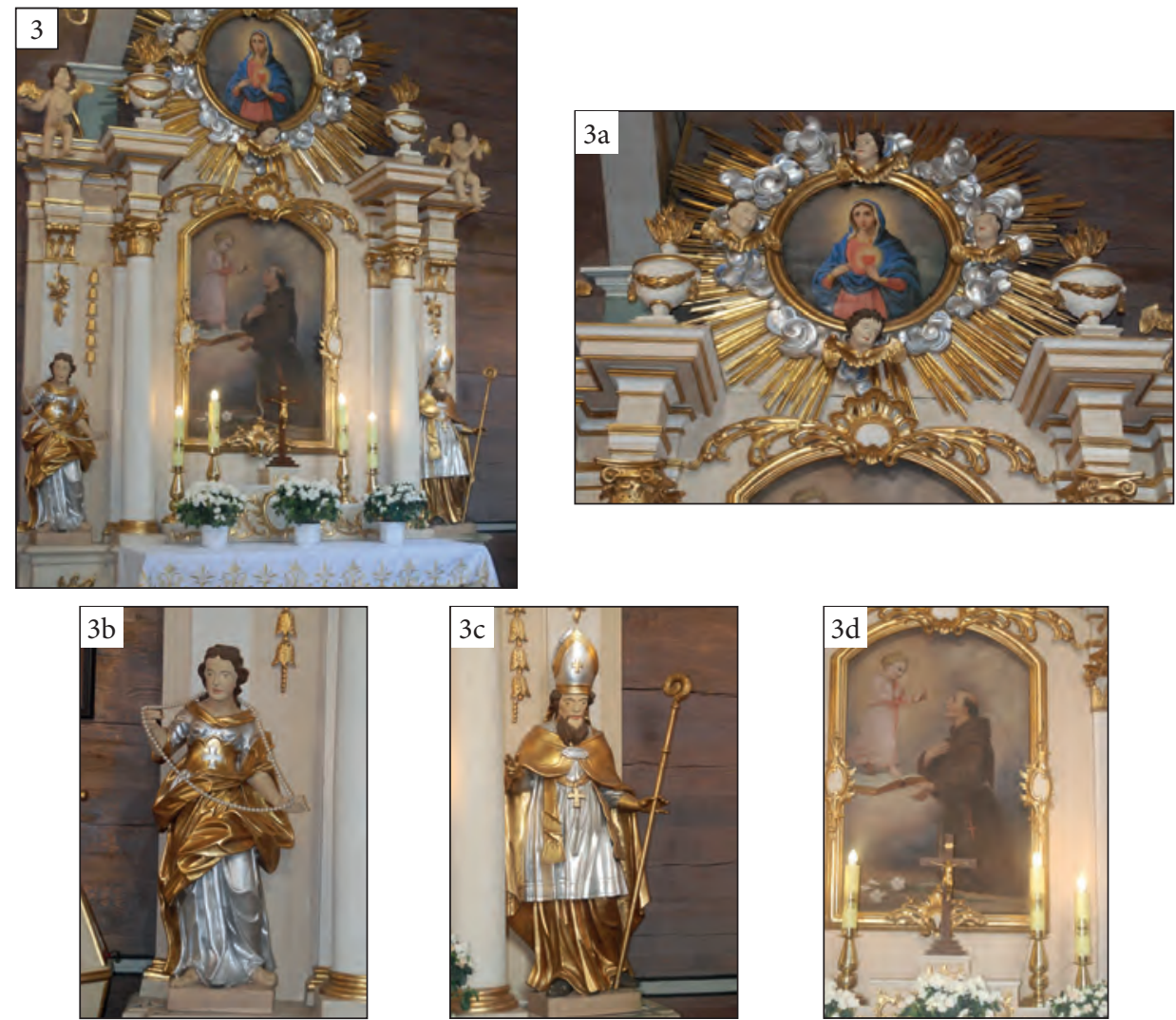

Fot. 3. Ołtarz kaplicy południowej w kościele św. Wawrzyńca w Rossoszycy:

$3 \mathrm{a}$ - obraz Serce Maryi, $3 \mathrm{~b}$ - rzeźba św. Apolonii, $3 \mathrm{c}$ - rzeźba św. Wojciecha, 3d - obraz św. Antoniego

Źródło: zdjęcia J. Pośpieszyński [12.05.2017]

\section{AMBONA I PROSPEKT ORGANOWY}

Drewniana ambona zawieszona jest na północnej ścianie prezbiterium. Składa się z kosza z parapetem, zaplecka i baldachimu. Kosz na rzucie wieloboku, z szerszą żłobkowaną zaokrągloną częścią dolną, zamknięty jest szyszką utworzoną z liści akantu. Boki kosza zdobią dwie płyciny oddzielone od siebie lizenami z ornamentem cekinowym. Kosz wieńczy parapet, gierowany na przedłużeniu lizen. Płyciny dekorujące kosz posiadają analogiczną kompozycję. W prostokątnym obramieniu $\mathrm{z}$ wyciętym do środka od dołu na osi łukiem półkolistym mieści się prostokąt, na bocznych przedłużonych osiach od dołu przyczepione są trójkątne 
łezki. W bocznej płycinie kosza, powyżej centralnej figury, dwoma śrubami przytwierdzona została dekoracja snycerska w postaci festonu imitującego tkaninę. Front ambony jest bardziej dekoracyjny. W płycinie, do naroży prostokąta z łezkami, przytwierdzona została forma na kształt festonu uformowanego z liści. Obramienie frontowej płyciny przerywa umieszczona na osi kanelowana konsolka, podtrzymująca zagierowany powyżej parapet. Konsolka otoczona jest płaskimi dekoracjami w formie chmurek i dwóch główek putt. W kształt łuku wyciętego od dołu w obramieniu płyciny wpisana jest połowa rozetki. Zaplecek zdobiony jest żłobkami, które kończą się w górnej partii półkolem. Na skrajach zaplecka, pod baldachimem, umieszczone są dwie główki aniołów. Baldachim posiada kształt wycinka koła. Do jego obrzeży podwieszone zostały festony imitujące tkaninę. W podniebiu baldachimu umieszczona jest gołębica w promienistej glorii. Baldachim wieńczy dekoracja złożona z wazy z wydostającymi się z niej płomieniami, tablicami dekalogu, otwartej księgi oraz dwóch trąb i okalających je chmur.
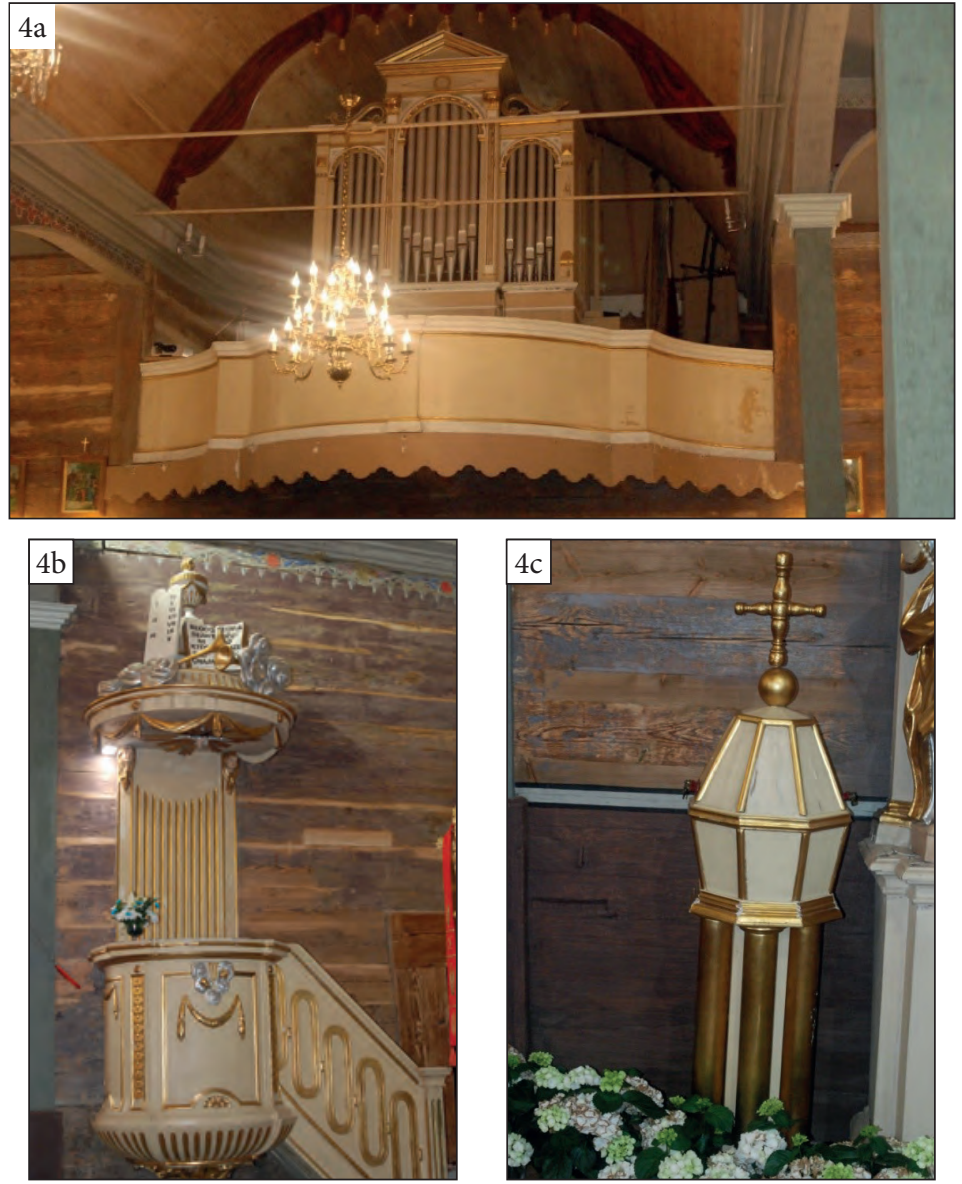

Fot. 4. Wyposażenie kościoła: 4a - prospekt organowy, 4b - ambona, 4c - chrzcielnica Źródło: fot. J. Pośpieszyński [12.05.2017] 
Prospekt organowy znajduje się na chórze muzycznym. Wykonany jest z drewna, w formie szafy, z motywem łuku triumfalnego. Najwyższą oś środkową ujmują dwa kanelowane ${ }^{19}$ pilastry o uproszczonych korynckich kapitelach ${ }^{20}$, dźwigające pas uproszczonego belkowania, na którym spoczywa trójkątny profilowany naczółek. Na skrajnych osiach całość zamykają lizeny, dekorowane u góry rautami i łezkami. One zaś utrzymują uproszczone belkowanie wieńczone parą esownic. Każda z trzech osi posiada wewnętrzną ramę kompozycyjną w postaci pary pilastrów, na których wspiera się łuk o powierzchni zdobionej pasem astragalu ${ }^{21}$. Ambona oraz prospekt organowy pochodzą z pocz. XIX w. ${ }^{22}$ Obecna polichromia utrzymana jest $\mathrm{w}$ odcieniach bieli i beżu, uzupełniona elementami złoconymi i srebrzonymi.

\section{UWAGI KOŃCOWE}

Prowadzone od 2014 r. prace remontowe pozwoliły na gruntowne odrestaurowanie bryły kościoła, a także umieszczonych w nim instalacji. Kolejny etap prac przewiduje malowanie wnętrza świątyni, aby przywrócić w miarę możliwości jej dawny wystrój. Prace konserwatorskie planowane w kolejnych latach będą obejmować renowację pozostających na wyposażeniu świątyni rzeźb i obrazów znajdujących się w ołtarzach.

Artykuł zawiera załączniki, w których prezentowane są zdjęcia wyposażenia kościoła w stanie, w jakim znajdują się obecnie, czyli na 2017 r.

\section{Bibliografia}

\section{Źródla archiwalne}

Archiwum Diecezjalne we Włocławku

Karta ewidencyjna zabytku ruchomego, zał. Ewa Kozołup, 1993.

Wiz. 8, Acta visitationis Archidiaconatus Vnieioviensis [...] in anno Dni 1683-tio felicitier expeditae.

Wiz. 73, Wizyta generalna do Decanatów Radomskiego, Brzeźnickiego i Lutomierskiego [w Archidiakonacie Uniejowskim] delegowanego wizytatora roku Pańskiego 1779 odprawiona.

19 Kanele - pionowe rowki wyżłobione na trzonie kolumny. Kanelować - ozdabiać żłobkowaniem trzon kolumny. Zob. Słownik języka polskiego, red. M. Szymczak, t. 1, PWN, Warszawa 1978 , s. 870

${ }^{20}$ Kapitel - głowica (kolumny). Kapitele korynckie - bogato zdobione głowice kolumn/pilastrów w kształcie odwróconego dzwonu. Zob. porządek koryncki.

${ }^{21}$ Astragal - perełkowanie, rodzaj nieznacznie wypukłego, ciągłego ornamentu zbudowanego z układu pojedynczych lub podwójnych pałeczek, przedzielonych perełkami, krążkami, paciorkami. Zob. W. Szolginia, Architektura, s. 15.

${ }^{22}$ Katalog zabytków sztuki w Polsce, t. II, z. 4, s. 17. 
Wojewódzki Konserwator Zabytków, Delegatura w Sieradzu.

\section{Opracowania}

Katalog zabytków sztuki w Polsce, t. II: Województwo łódzkie, red. J. Łoziński, z. 10, Warszawa 1953.

Krajewski K., Mała encyklopedia architektury $i$ wnętrz, Zakład Narodowy Ossolińskich, Wrocław 1974.

Łosski W., Hodegeria-Putiwoditielnica, „Przegląd Prawosławny” 2002, nr 8 (206).

Migasiewicz P., Dzieła rzébiarza Franza Eytnera na terenie dawnych ziem łęczyckiej i sieradzkiej, [w:] Sztuka Polski Środkowej. Studia V, red. P. Gryglewski, E. Kubiak, K. Stefański, Łódź 2011.

Porębski M., Dzieje sztuki w zarysie. Od paleolitu po wieki średnie, t. 1, Arkady, Warszawa 1976.

Słownik języka polskiego, red. M. Szymczak, t. 1, PWN, Warszawa 1978.

Stownik terminologiczny sztuk pięknych, red. S. Kozakiewicz, Warszawa 1969.

Słownik terminologiczny sztuk pięknych, Wyd. Naukowe PWN, Warszawa 2007.

Szolginia W., Architektura, Sigma NOT, Warszawa 1992.

Sztuka świata, t. 17: Stownik terminów A-K, Arkady, Warszawa 2013.

Wielka Encyklopedia Powszechna, t. 9, PWN, Warszawa 1967.

\section{Strony internetowe}

http://www.przegladprawoslawny.pl/articles.php?id_n=169\&id=8 [dostęp 7.05.2017].

[Wpłynęło: marzec; poprawiono: czerwiec 2017 r.]

\section{INTERIOR OF THE CHURCH OF ST. LAWRENCE IN ROSSOSZYCA}

\section{Summary}

The Church of St. Lawrence in Rossoszyca (municipality of Warta) is among the most interesting and valuable 18th century sacral buildings in Włocławek diocese. The beautiful building constructed of larch wood is now undergoing extensive restoration. The equipment of the church, mostly from the 18th century, includes three altars, probably created in the wood-carving workshop of franz Eytner, an artist from Kalisz, famous for his expressive sculptures.

Keywords: Church of St.Lawrence in Rossoszyca, church equipment. 